\title{
Bone Morphogenetic Proteins Induce the Expression of Noggin, Which Limits Their Activity in Cultured Rat Osteoblasts
}

\author{
Elisabetta Gazzerro, Valerie Gangji, and Ernesto Canalis \\ Departments of Research and Medicine, Saint Francis Hospital and Medical Center, Hartford, Connecticut 06105; and The University of \\ Connecticut School of Medicine, Farmington, Connecticut 06030
}

\begin{abstract}
Bone morphogenetic proteins (BMPs) induce the differentiation of cells of the osteoblastic lineage and enhance the function of the osteoblast. Growth factors are regulated by binding proteins, but there is no information about binding proteins for BMPs in skeletal cells. Noggin specifically binds BMPs, but its expression by cells of the osteoblastic lineage has not been reported. We tested for the expression of noggin and its induction by BMP-2 in cultures of osteoblast-enriched cells from 22-d-old fetal rat calvariae $(\mathrm{Ob}$ cells). BMP-2 caused a time- and dose-dependent increase in noggin mRNA and polypeptide levels, as determined by Northern and Western blot analyses. The effects of BMP-2 on noggin transcripts were dependent on protein, but independent of DNA synthesis. BMP-2 increased the rates of noggin transcription as determined by nuclear run-on assays. BMP-4, BMP-6, and TGF- $\beta 1$ increased noggin mRNA in $\mathrm{Ob}$ cells, but basic fibroblast growth factor, plateletderived growth factor BB, and IGF-I did not. Noggin decreased the stimulatory effects of BMPs on DNA and collagen synthesis and alkaline phosphatase activity in $\mathrm{Ob}$ cells. In conclusion, BMPs induce noggin transcription in Ob cells, a probable mechanism to limit BMP action in osteoblasts. (J. Clin. Invest. 1998. 102:2106-2114.) Key words: binding proteins $\cdot$ bone formation - chordin - osteogenic proteins $\bullet$ transcription
\end{abstract}

\section{Introduction}

Bone morphogenetic proteins (BMPs) ${ }^{1}$ are members of the TGF- $\beta$ superfamily of polypeptides, which have a conserved carboxy-terminal region containing seven cysteine repeats $(1$, 2). Multiple BMPs or osteogenic proteins (OPs) have been de-

Address correspondence to Ernesto Canalis, M.D., Department of Research, Saint Francis Hospital and Medical Center, 114 Woodland Street, Hartford, CT 06105-1299. Phone: 860-714-4068; FAX: 860714-8053; E-mail: ecanalis@stfranciscare.org

Received for publication 17 March 1998 and accepted in revised form 15 October 1998.

1. Abbreviations used in this paper: APA, alkaline phosphatase activity; bFGF, basic fibroblast growth factor; BMPs, bone morphogenetic proteins; CDP, collagenase-digestible protein; ECM, extracellular matrix; IGFBP, insulin-like growth factor binding protein; NCP, noncollagen protein; $\mathrm{Ob}$ cells, osteoblast-enriched cells from 22-day-old fetal rat calvaria; OP, osteogenic protein; SSC, saline sodium citrate.

J. Clin. Invest.

(C) The American Society for Clinical Investigation, Inc. 0021-9738/98/12/2106/09 \$2.00

Volume 102, Number 12, December 1998, 2106-2114

http://www.jci.org scribed, including BMP-2, -3 (or osteogenin), -4, -5, -6, -7 (or OP1), and -8 (or OP2) (1-7). BMPs are known for their role in embryonic development and differentiation. They also have modest mitogenic properties for skeletal cells, induce the differentiation of mesenchymal cells into osteogenic cells, and enhance the differentiated function of the osteoblast (8-13). BMPs increase collagen synthesis and inhibit collagenase 3 expression by the osteoblast $(9,14)$. This suggests that they may play a role in the maintenance of bone mass by decreasing collagen degradation.

Cells of the osteoblastic lineage express BMP-2, -4 , and -6 , and BMP-6 mediates the effects of glucocorticoids on osteoblastic cell differentiation $(15,16)$. This indicates a role for BMPs as local regulators of osteoblastic differentiation and function. Local regulators of skeletal cells can be modulated at the level of synthesis, receptor binding, and binding proteins (17). However, there is limited information about the regulation of BMPs at any of these levels. BMP receptors have been characterized, and recently, the existence of binding proteins specific for the closely related BMP-2 and -4 have been reported (18-21). Noggin and chordin are secreted glycoproteins with a respective molecular mass $\left(M_{\mathrm{r}}\right)$ of $64 \mathrm{kD}$ and $120 \mathrm{kD}$, and are synthesized by the Spemann organizer of the amphibian gastrula $(22,23)$. Noggin and chordin mimic the actions of the Spemann organizer, which can induce the formation of neural tissue from ectoderm and induce dorsalization of the ventral mesoderm and form muscle. These activities are opposed by BMPs, and noggin and chordin bind and block the actions of BMP-2 and -4 by preventing receptor binding (2426). In mammals, noggin is expressed primarily, but not exclusively, in the central nervous system (27). Although it was shown to prevent the effects of BMP-4 on the differentiation of bone marrow cells, the expression and actions of noggin in osteoblastic cells are unknown (24). We postulated that noggin, or possibly chordin, may be expressed by cells of the osteoblastic lineage to limit BMP actions in the osteoblast. This would be a critical function for a BMP binding protein since excessive BMP-4 has been implicated in the pathogenesis of fibrodysplasia ossificans progressiva (28).

In the present study, we examined the expression of noggin and chordin in cultures of osteoblast-enriched cells from 22$\mathrm{d}$-old fetal rat calvaria ( $\mathrm{Ob}$ cells), and determined whether or not they were regulated by BMPs. We also examined whether noggin modified the expression of BMPs in osteoblasts and the effects of BMPs on the replication and function of osteoblastic cells.

\section{Methods}

Culture technique. The culture method used was described in detail previously (29). Parietal bones were obtained from 22-d-old fetal rats immediately after the mothers were sacrificed by blunt trauma to the nuchal area. This project was approved by the Institutional Animal Care and Use Committee of Saint Francis Hospital and Medical Cen- 
ter. Cells were obtained by five sequential digestions of the parietal bone using bacterial collagenase (CLS II; Worthington Biochemical, Freehold, NJ). Cell populations harvested from the third to the fifth digestions were cultured as a pool and were previously shown to have osteoblastic characteristics (29). Ob cells were plated at a density of $8,000-12,000$ cells $/ \mathrm{cm}^{2}$ and cultured in a humidified $5 \% \mathrm{CO}_{2}$ incubator at $37^{\circ} \mathrm{C}$ until reaching confluence (about $50,000 \mathrm{cells} / \mathrm{cm}^{2}$ ). For the nuclear run-on experiments, first-passage cultures were used. Rat skin fibroblasts were obtained by collagenase digestion of the skin of 22-d-old fetal rats, and tested after three to four passages (30). Ob cells and fibroblasts were cultured in Dulbecco's modified Eagle's medium (DMEM; Life Technologies, Grand Island, NY), supplemented with nonessential amino acids and 10\% FBS (Summit Biotechnologies, Fort Collins, CO). Immortalized osteoblastic MC3T3E1 cells were plated at a density of $14,000 \mathrm{cells} / \mathrm{cm}^{2}$ in $\alpha$-MEM (Life Technologies) containing $20 \mathrm{mM}$ HEPES and $10 \%$ FBS and grown under the same conditions as Ob cells to confluence (about 100,000 cells $/ \mathrm{cm}^{2}$ ) (31). Confluent fibroblasts, Ob cells, and MC3T3-E1 cells were exposed to serum-free medium for 20-24 $\mathrm{h}$ and then exposed to test or control medium in the absence of serum for 2-48 h. In 48-h treated cultures, the medium was replaced after $24 \mathrm{~h}$ with fresh control or test solutions. Hydroxyurea (Sigma Chemical Co., St. Louis, MO), recombinant human BMP-2 (a gift from Genetics Institute, Cambridge, MA), TGF- $\beta 1$ (a gift from Genentech, South San Francisco, CA), basic fibroblast growth factor (bFGF), PDGF BB, and IGF-I (all from Austral, San Ramon, CA) were added directly to the medium. Cycloheximide (Sigma Chemical Co.) was dissolved in ethanol and diluted 1:1,000 in DME, and recombinant human BMP-4 and BMP-6 (gifts from Genetics Institute) were dissolved in $0.1 \%$ trifluoracetic acid and diluted 1:8,000 and 1:4,000 in DMEM. Control cultures contained equal amounts of solvent. Recombinant human noggin was expressed in Escherichia coli (a gift from Regeneron Pharmaceuticals, Inc., Tarrytown, NY), repurified, and dissolved in 50 $\mathrm{mM}$ sodium chloride, $1 \mathrm{mM}$ magnesium acetate, $20 \%$ glycerol, and diluted 1:10,000 or greater in DMEM. For RNA analysis, the cell layer was extracted with guanidine thiocyanate at the end of the incubation and stored at $-70^{\circ} \mathrm{C}$. For the nuclear run-on assay, nuclei were isolated by Dounce homogenization. For noggin protein analysis, the medium was collected in the presence of $0.1 \%$ polyoxyethylene sorbitan monolaurate (Tween-20; Pierce Chemical Co., Rockford, IL), and the extracellular matrix (ECM) was extracted and stored at $-70^{\circ} \mathrm{C}$. For DNA and protein synthesis and alkaline phosphatase activity (APA) the cell layer was extracted and stored at $-70^{\circ} \mathrm{C}$.

Northern blot analysis. Total cellular RNA was isolated using the RNeasy kit per manufacturer's instructions (Qiagen, Chatsworth, CA). The RNA recovered was quantitated by spectrometry, and equal amounts of RNA from control or test samples were loaded on a formaldehyde agarose gel following denaturation. The gel was stained with ethidium bromide to visualize RNA standards and ribosomal RNA, confirming equal RNA loading of the various experimental samples. The RNA was blotted onto GeneScreen Plus charged nylon (DuPont, Wilmington, DE), and uniformity of transfer was confirmed by revisualization of ethidium bromide stained ribosomal RNA. A $1.0 \mathrm{~kb}$ Bam HI/Not I human noggin cDNA (a gift from Regeneron), a $3.8 \mathrm{~kb}$ Hind III/Xba I Xenopus chordin cDNA (a gift from E.M. De Robertis, University of California at Los Angeles, Los Angeles, CA), a 240 bp Hind III/Eco RI murine BMP-2, a 285 bp Pst I/Eco RI murine BMP-4, and a 190 bp Eco RI/Hind III murine BMP-6 cDNA (all gifts from Genetics Institute) were purified by agarose gel electrophoresis and labeled with $\left[\alpha-{ }^{32} \mathrm{P}\right]$ deoxycytidine triphosphate and $\left[\alpha-{ }^{32} \mathrm{P}\right]$ deoxyadenosine triphosphate $(50 \mu \mathrm{Ci}$ each at a specific activity of 3,000 Ci/mmol; DuPont-NEN, Boston, MA) using the random hexanucleotide-primed second-strand synthesis method $(1,2,23$, 27,32 ). Hybridizations were carried out at $42^{\circ} \mathrm{C}$ for $16-72 \mathrm{~h}$, followed by two posthybridization washes at room temperature for $15 \mathrm{~min}$ in $1 \times$ saline sodium citrate (SSC), and a third wash was performed at $65^{\circ} \mathrm{C}$ for $30 \mathrm{~min}$ in $0.5 \times \mathrm{SSC}$ for noggin, $1 \times \mathrm{SSC}$ for chordin and BMP-2, and $0.2 \times$ SSC for BMP- 4 and BMP- 6 . The blots were stripped and re- hybridized with an $\alpha{ }^{-32} \mathrm{P}$-labeled 752 bp Bam HI/Sph I restriction fragment of the murine $18 \mathrm{~S}$ ribosomal RNA cDNA (American Type Culture Collection, Rockville, MD) under the conditions described followed by two posthybridization washes in $1 \times$ SSC at room temperature and one at $65^{\circ} \mathrm{C}$ for $20 \mathrm{~min}$ in $0.1 \times \mathrm{SSC}$. An excess of unlabeled $18 \mathrm{~S}$ cDNA was mixed with the $\alpha{ }^{-32} \mathrm{P}$-labeled probe before adding to the hybridization mixture to ensure a sufficient quantity of $18 \mathrm{~S}$ cDNA to bind the $18 \mathrm{~S}$ rRNA. The bound radioactive material was visualized by autoradiography on Kodak X-AR5 film (Eastman Kodak, Rochester, NY), employing Cronex Lightning Plus (DuPont) or Biomax MS (Eastman Kodak) intensifying screens. Relative hybridization levels were determined by densitometry. Northern analyses shown are representative of three of more cultures.

Nuclear run-on assay. To examine changes in the rate of transcription, nuclei were isolated by Dounce homogenization in a Tris buffer containing $0.5 \%$ Nonidet P-40 (33). Nascent transcripts were labeled by incubation of nuclei in a reaction buffer containing 500 $\mu \mathrm{M}$ each adenosine, cytidine, and guanosine triphosphates, $150 \mathrm{U}$ of RNasin (Promega, Madison, WI), and $250 \mu \mathrm{Ci}$ of $\left[\alpha{ }^{-32} \mathrm{P}\right]$ uridine triphosphate (3,000 Ci/mM; DuPont) (33). RNA was isolated by treatment with DNase I and proteinase $\mathrm{K}$, followed by phenol-chloroform extraction and ethanol precipitation. Linearized noggin cDNA was immobilized onto GeneScreen Plus by slot blotting according to manufacturer's directions (DuPont). The plasmid vector pGL2-Basic (Promega) was used as a control for nonspecific hybridization, and $18 \mathrm{~S}$ ribosomal RNA cDNA was used to estimate uniformity of counts applied to the membrane. Equal counts per minute of $\alpha-{ }^{32} \mathrm{P}$-labeled RNA from each sample were hybridized to cDNAs at $42^{\circ} \mathrm{C}$ for $72 \mathrm{~h}$ and washed in $1 \times \mathrm{SSC}$ at $65^{\circ} \mathrm{C}$ for $60 \mathrm{~min}$. Hybridized cDNAs were visualized by autoradiography.

Western blot analysis. To prepare ECM extracts, Ob cells were rinsed in PBS, cell membranes were removed with $0.5 \%$ Triton X-100, and nuclei and cytoskeleton were removed with $25 \mathrm{mM}$ ammonium acetate, $\mathrm{pH} 9$, in the absence of lathyrogen or guanidine $\mathrm{HCl}(34,35)$. The ECM was rinsed with PBS, and ECM or medium aliquots were mixed with Laemmli sample buffer to give a final concentration of $2 \%$ SDS and fractionated by PAGE on an $8 \%$ denaturing gel in the absence of reducing agents (36). For Western immunoblots, proteins were transferred to Immobilon $\mathrm{P}$ membranes (Millipore, Bedford, MA), blocked with $2 \% \mathrm{BSA}$, and exposed to $20 \mathrm{ng} / \mathrm{ml}$ of a rat $\mathrm{mAb}$ raised against human noggin (RP57-16, a gift from Regeneron) in 1\% BSA overnight. Blots were exposed to a goat anti-rat IgG antiserum conjugated to horseradish peroxidase and developed with a horseradish peroxidase chemiluminescent detection reagent. Western blots are representative of three or more cultures.

$D N A$, collagen, and noncollagen protein synthesis. DNA synthesis was studied by measuring effects on the incorporation of [methyl$\left.{ }^{3} \mathrm{H}\right]$ thymidine $(5 \mu \mathrm{Ci} / \mathrm{ml}$, specific activity $78 \mathrm{Ci} / \mathrm{mmol}$; DuPont $)$ into acid-insoluble extracts during the last $2 \mathrm{~h}$ of culture, as previously described (37). Data are expressed as disintegrations per minute (dpm) per $0.32-\mathrm{cm}^{2}$ culture well. Collagen synthesis was determined by measuring the incorporation of $2,3-{ }^{3} \mathrm{H}$-labeled proline $(12.5 \mu \mathrm{Ci} / \mathrm{ml}$, specific activity $40 \mathrm{Ci} / \mathrm{mmol}$; DuPont) into collagen for the last $2 \mathrm{~h}$ of the culture (37). Cells were extracted and homogenized as described and incubated with repurified bacterial collagenase (Worthington Biochemical Corp.). The labeled proline incorporated into collagenasedigestible protein (CDP) and noncollagen protein (NCP) was measured according to the method of Peterkofsky and Diegelmann (38). Data are expressed as dpm per 2- $\mathrm{cm}^{2}$ culture well. The percentage of collagen synthesis was calculated after multiplying NCP by 5.4 to correct for the relative abundance of proline in CDP and NCP.

$A P A$. APA was determined in $0.5 \%$ Triton $\mathrm{X}-100$ cell extracts by hydrolysis of p-nitrophenyl phosphate to p-nitrophenol and measured by spectroscopy at $410 \mathrm{~nm}$ after $30 \mathrm{~min}$ of incubation according to the manufacturer's instructions (Sigma Chemical Co.). Data are expressed as picomoles of p-nitrophenol released per minute per microgram of protein. Total protein content in the extracts was determined by the Coomassie brilliant blue G-250 dye-binding assay of 


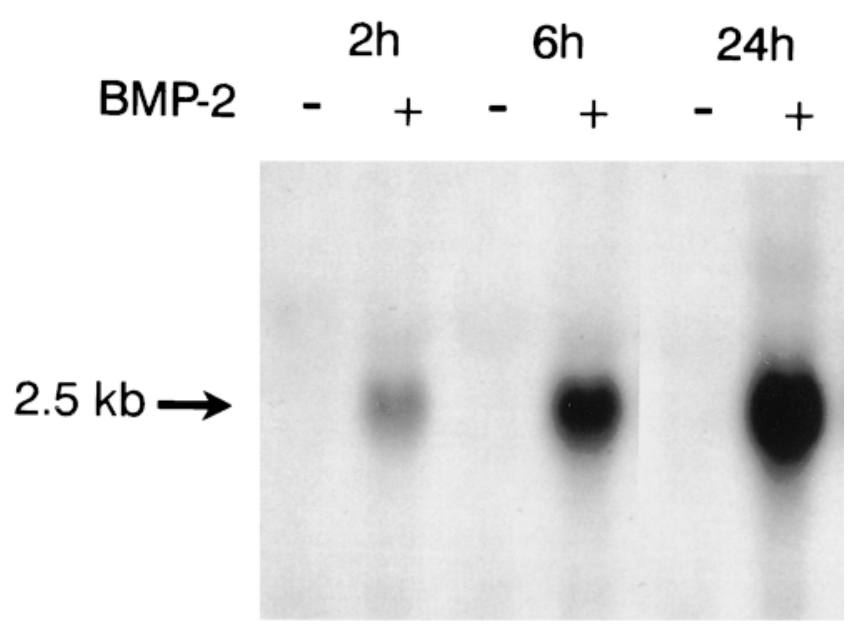

$18 S$

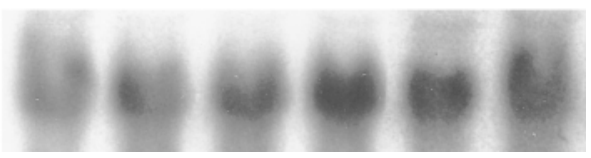

Figure 1. Effect of BMP-2 at $3.3 \mathrm{nM}$ on noggin mRNA expression in cultures of $\mathrm{Ob}$ cells treated for 2,6 , or $24 \mathrm{~h}$. Total RNA from control $(-)$ or BMP-2-treated cultures (+) was subjected to Northern blot analysis and hybridized with an $\alpha^{-}{ }^{32} \mathrm{P}$-labeled noggin cDNA. The blot was stripped and rehybridized with labeled $18 \mathrm{~S}$ cDNA. Noggin mRNA was visualized by autoradiography and is shown in the upper panel, while $18 \mathrm{~S}$ ribosomal RNA is shown in the lower panel.

Bradford in accordance with the manufacturer's instructions (BioRad Laboratories, Richmond, CA).

Statistical analysis. Data are expressed as means \pm SEM. Statistical differences were determined by ANOVA and post hoc examination by the Ryan-Einot-Gabriel-Welch $F$ test or Dunnett's test using a Crunch Statistical Package (Crunch Software Corp., Oakland, CA) (39).

\section{Results}

Untreated cultures of $\mathrm{Ob}$ cells did not express clearly detectable levels of noggin mRNA by Northern blot analysis. However, treatment of Ob cells with BMP-2 caused a time- and dose- dependent induction of noggin mRNA expression. BMP-2 at $3.3 \mathrm{nM}$ induced noggin transcripts of $2.5 \mathrm{~kb}$ after $2 \mathrm{~h}$ (Fig. 1). The effect was nearly maximal after $6 \mathrm{~h}$ and was sustained for $24 \mathrm{~h}$. The stimulatory effect of BMP-2 was observed at concentrations of $0.3-3.3 \mathrm{nM}(10-100 \mathrm{ng} / \mathrm{ml})$ after $6 \mathrm{~h}$ and $24 \mathrm{~h}$ (Fig. 2). In contrast, chordin transcripts were not detected by Northern blot analysis in control or BMP-2-treated Ob cells (data not shown). Western blot analysis of ECM extracts or conditioned medium from $\mathrm{Ob}$ cells revealed that BMP-2 at $3.3 \mathrm{nM}$ for $24 \mathrm{~h}$ induced an immunoreactive protein with a $M_{\mathrm{r}}$ of 64 kD, the known $M_{\mathrm{r}}$ of glycosylated noggin dimers (Fig. 3) (22, 24). There was no immunoreactive noggin detected in the medium of control cultures, and a minimal amount was detected in their ECM. A faint additional band, migrating with a $M_{\mathrm{r}}$ of 46 $\mathrm{kD}$ was detected in the ECM. This band comigrated with a recombinant unglycosylated human noggin standard (data not shown), indicating that it was probably nonglycosylated noggin.

To determine whether or not the effects of BMP-2 on noggin mRNA expression were dependent on protein or DNA synthesis, Ob cells were exposed to BMP-2 in the presence and absence of the protein synthesis inhibitor cycloheximide or the DNA synthesis inhibitor hydroxyurea. Neither cycloheximide at $3.6 \mathrm{uM}$ nor hydroxyurea at $1 \mathrm{mM}$, doses known to block protein and DNA synthesis, respectively, in $\mathrm{Ob}$ cells, prevented the induction of noggin by BMP-2 (data not shown) $(40,41)$. To determine whether or not BMP-2 modified the transcription of the noggin gene, nuclear run-on assays were performed on nuclei from $\mathrm{Ob}$ cells treated for 2-24 h. These assays demonstrated that BMP-2 induced the rate of noggin transcription after $2 \mathrm{~h}$, an effect that was sustained for $24 \mathrm{~h}$ (Fig. 4).

Similar to the effect of BMP-2, BMP-4 and BMP-6 caused a time- and dose-dependent induction of noggin mRNA (Fig. 5). The induction was noted after $2 \mathrm{~h}$, was sustained for $24 \mathrm{~h}$, and was of similar magnitude for the three BMPs, which induced noggin transcripts to a similar extent (Fig. 5). TGF- $\beta 1$ at $1.2 \mathrm{nM}$ induced noggin mRNA levels in Ob cells after $2 \mathrm{~h}$, but the effect was not detectable after $6 \mathrm{~h}$ or $24 \mathrm{~h}$ (Fig. $6 \mathrm{~A}$ ). The induction of noggin mRNA in Ob cells appeared selective to BMPs and TGF- $\beta 1$, and treatment with other growth factors at doses effective in Ob cells such as bFGF at $1.7 \mathrm{nM}$, PDGF BB at $3.3 \mathrm{nM}$, or IGF-I at $100 \mathrm{nM}$ for 2,6 , or $24 \mathrm{~h}$ did not induce noggin mRNA levels (Fig. 6 a) (37, 41, 42). Furthermore,

$6 \mathrm{~h}$

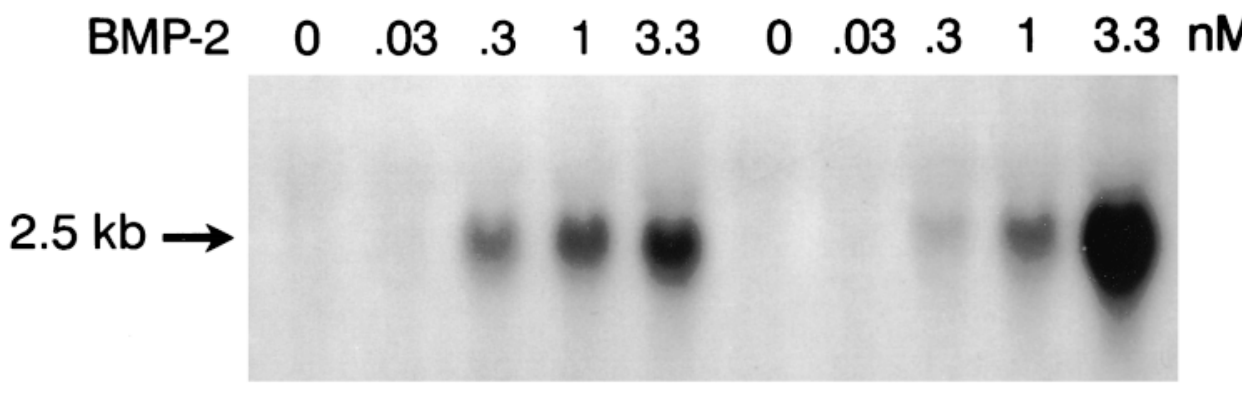

$18 S$

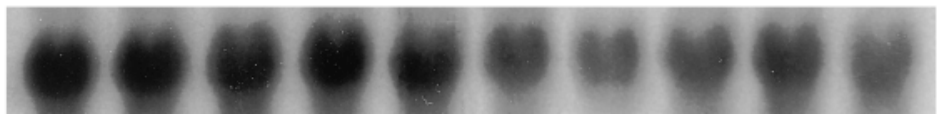

Figure 2. Effect of BMP-2 at $0.03-$ $3.3 \mathrm{nM}$ on noggin mRNA expression in cultures of $\mathrm{Ob}$ cells treated for $6 \mathrm{~h}$ or $24 \mathrm{~h}$. Total RNA from control (0) or treated cultures was subjected to Northern blot analysis and hybridized with an $\alpha-{ }^{32} \mathrm{P}$-labeled noggin cDNA. The blot was stripped and rehybridized with labeled 18 S cDNA. Noggin mRNA was visualized by autoradiography and is shown in the upper panel while $18 \mathrm{~S}$ ribosomal RNA is shown below. 



Figure 3. Effect of BMP-2 at $3.3 \mathrm{nM}$ on noggin polypeptide levels in cultures of $\mathrm{Ob}$ cells treated for $24 \mathrm{~h}$. A $100-\mu \mathrm{l}$ aliquot of conditioned medium, representing $1 / 7.5$ th of a culture well (left panel), or a $200-\mu 1$ aliquot of ECM, representing 2/5th of a culture well (right panel), from control ( -$)$ and BMP-2-treated cultures $(+)$ was subjected to Western immunoblot analysis, and noggin was detected using an antinoggin antibody and a chemiluminescence detection system. Migration of molecular weight markers $(\mathrm{kD})$ is indicated on the left.

bFGF and PDGF BB, but not IGF-I, opposed the stimulatory effect of BMP-2 on noggin mRNA expression (Fig. $6 \mathrm{~B}$ ). The stimulatory effect of TGF- $\beta 1$ was short-lived and observed at concentrations of 4-1,200 pM (Fig. 7). In the same experiment, BMP-2, -4 , and -6 at $0.3-3.3 \mathrm{nM}$ for $24 \mathrm{~h}$ caused a more pronounced increase in noggin transcripts (Fig. $5 b$ ).

BMP-2 also increased noggin mRNA levels in the MC3T3 osteoblastic cell line, although the onset of the stimulatory effect was observed after $24 \mathrm{~h}$ instead of after $6 \mathrm{~h}$ as shown in $\mathrm{Ob}$ cells (data not shown). The effect of BMP-2 on noggin expression was not specific to osteoblasts and was also observed in cultured rat skin fibroblasts. However, the effect in fibroblasts was of a smaller magnitude and shorter duration than that observed in osteoblasts and BMP-2-induced noggin transcripts in fibroblasts after $2 \mathrm{~h}$ and $6 \mathrm{~h}$, but not after $24 \mathrm{~h}$ (data not shown). In contrast to the effects of BMPs on noggin expression, noggin at $1.8 \mathrm{nM}(100 \mathrm{ng} / \mathrm{ml})$ after $2,6,24$, or $48 \mathrm{~h}$ did not alter the expression of BMP-2 and BMP- 6 and caused only a small increase of (mean \pm SEM, $n=8) 1.4 \pm 0.1$-fold in BMP-4 mRNA levels in Ob cells after $24 \mathrm{~h}$ (data not shown).

To confirm that noggin modified cellular functions regulated by BMPs, the effects of BMP-2 on DNA and collagen synthesis, and APA in Ob cells were examined in the presence and absence of noggin at $1.8 \mathrm{nM}(100 \mathrm{ng} / \mathrm{ml})$. After $24 \mathrm{~h}, \mathrm{BMP}-2$ at $0.3-3.3 \mathrm{nM}(10-100 \mathrm{ng} / \mathrm{ml})$ caused a dose-dependent stimulation on the incorporation of $\left[{ }^{3} \mathrm{H}\right]$ thymidine into DNA and on the incorporation of ${ }^{3} \mathrm{H}$-labeled proline into collagen and noncollagen protein, and BMP-2 at 1-3.3 nM increased APA (Fig. 8). The effect of BMP-2 on collagen and noncollagen labeling was comparable; therefore, the percent of collagen synthesized was not changed (data not shown). Noggin at $1.8 \mathrm{nM}$ decreased the effect of BMP-2 at $1 \mathrm{nM}$ and lower concentrations on DNA and collagen synthesis and the effect of BMP-2 at 3.3 $\mathrm{nM}$ and lower concentrations on noncollagen protein synthesis and APA in Ob cells. BMP-4 and BMP-6 had analogous effects to those of BMP-2 and increased DNA and collagen synthesis in Ob cells (Fig. 9). Their stimulatory effect, like that of BMP-2, also was opposed by noggin at $1.8 \mathrm{nM}$.

\section{Discussion}

BMPs induce the differentiation of precursor cells into cells of the osteoblastic lineage and have important actions on the function of the osteoblast. Noggin was recently shown to bind BMPs with high affinity, and as a consequence block their biological effects (24). The present studies reveal that while unstimulated rat osteoblasts do not express detectable levels of noggin mRNA, BMP-2, -4 , and -6 cause a similar induction of noggin transcripts. In contrast, chordin transcripts were not detected in control or BMP-treated Ob cells. The stimulatory effect of BMP-2 was studied in detail and found to be time- and dose-dependent and to be associated with an increase in noggin polypeptide levels, indicating that BMP-2 induces noggin synthesis. The effect of BMP-2 on noggin mRNA was fairly acute and unrelated to the modest mitogenic properties of the

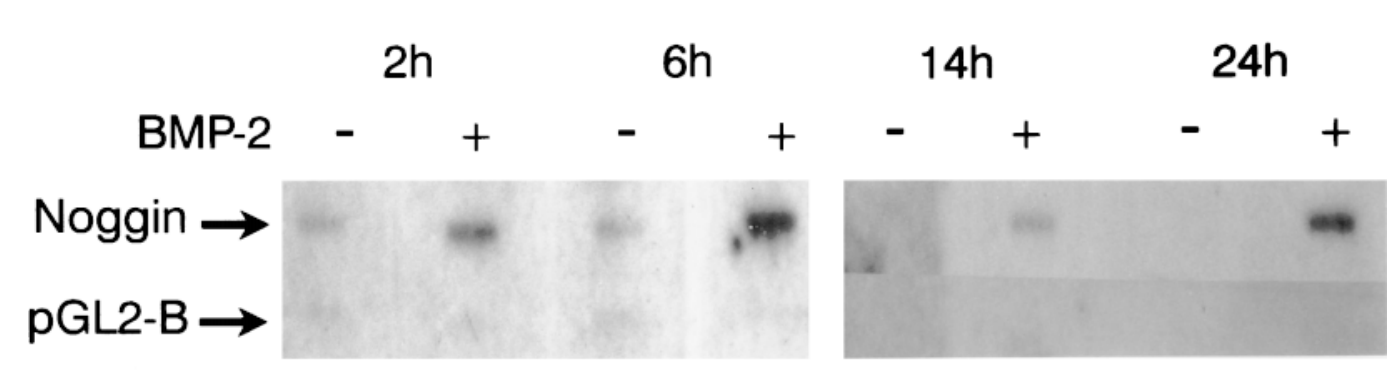

$18 \mathrm{~S} \rightarrow+2=$
Figure 4. Effect of BMP-2 on noggin transcription rates in cultures of $\mathrm{Ob}$ cells treated for $2 \mathrm{~h}$ and $6 \mathrm{~h}(\mathrm{ex}-$ periment $\mathrm{A}$ ) or $14 \mathrm{~h}$ and $24 \mathrm{~h}$ (experiment B). Nascent transcripts from control $(-)$ or BMP-2 $(+)$-treated cultures were labeled in vitro with $\left[\alpha-{ }^{32} \mathrm{P}\right]$ uridine triphosphate, and the labeled RNA was hybridized to immobilized cDNA for noggin. 18S cDNA was used to demonstrate loading, and pGL2-Basic vector DNA was used as a control for nonspecific hybridization. 


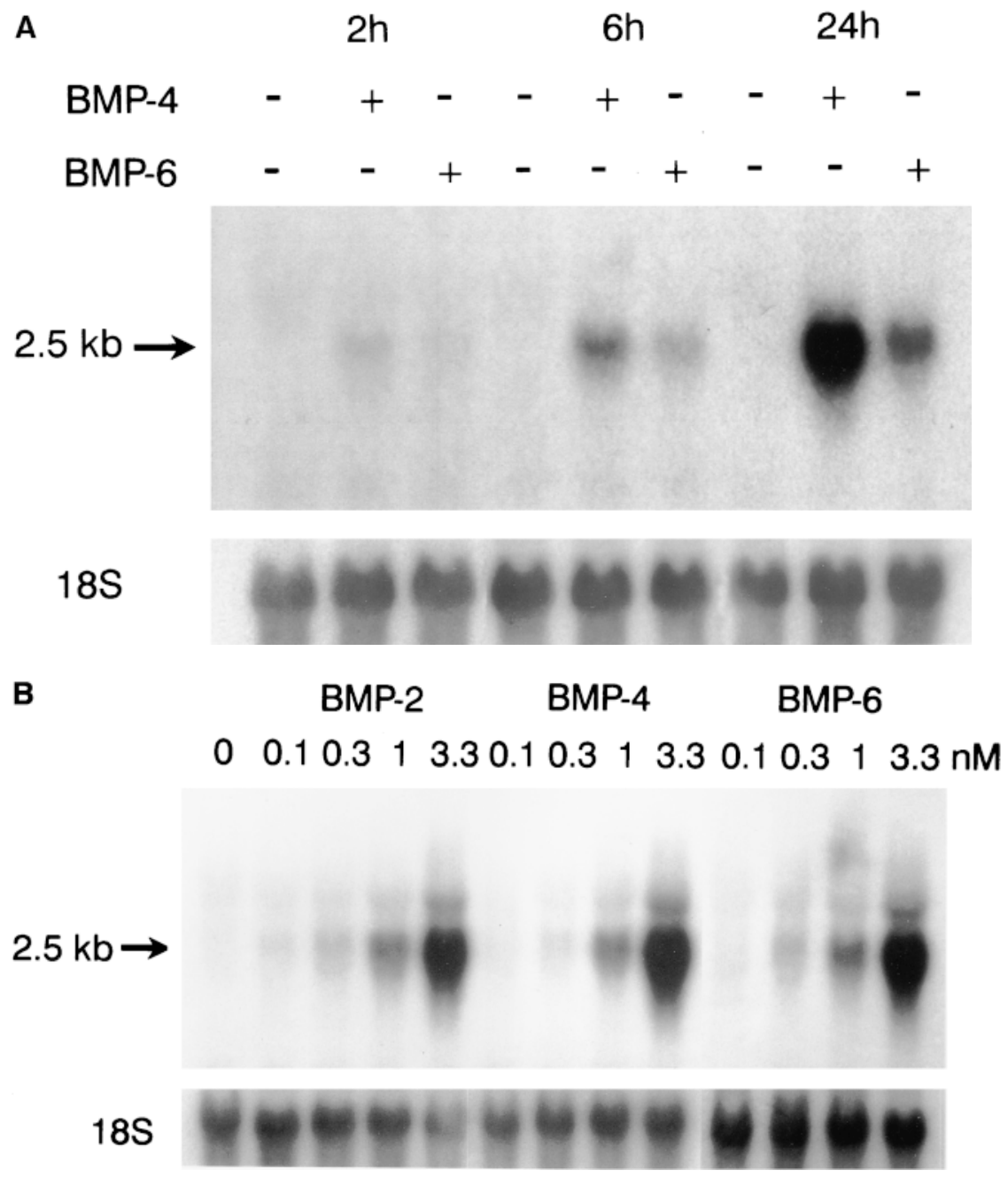

Figure 5. Effect of BMP-2, -4 , and -6 on noggin mRNA expression in cultures of Ob cells. (A) Ob cells were treated for 2,6 , or $24 \mathrm{~h}$ with BMP-4 or BMP-6 at $3.3 \mathrm{nM}$. (B) Ob cells were treated for $24 \mathrm{~h}$ with BMP-2, -4 , or -6 at $0.1-3.3$ nM. Total RNA from control ( - or 0$)$ or BMP-treated cultures was subjected to Northern blot analysis and hybridized with an $\alpha-{ }^{32} \mathrm{P}-$ labeled noggin cDNA. The blot was stripped and rehybridized with labeled $18 \mathrm{~S}$ cDNA. Noggin mRNA was visualized by autoradiography and is shown in the upper panels, while $18 \mathrm{~S}$ ribosomal RNA is shown below. growth factor. BMP-2 induced noggin expression by transcriptional mechanisms. A stimulation of noggin mRNA levels in $\mathrm{Ob}$ cells was also observed with the related peptide TGF- $\beta 1$, although the induction of noggin by TGF- $\beta 1$ was short-lived, and the effect of a lesser magnitude from that of BMPs. TGF$\beta 1$ induced noggin mRNA at concentrations lower than those of BMPs, but this is in line with other effects of TGB- $\beta$ and BMPs in cells of the osteoblastic lineage $(43,44)$. The reason for the short duration of the TGF- $\beta 1$ effect on noggin mRNA levels is not clear. It is possible that TGF- $\beta 1$ induces noggin transcription and also destabilizes noggin transcripts.

Other growth factors synthesized by skeletal cells and known to have important functions on cells of the osteoblastic lineage, such as bFGF, PDGF BB, and IGF-I, did not modify noggin mRNA levels in $\mathrm{Ob}$ cells (17). These results indicate that the induction of noggin in osteoblastic cells is relatively selective to members of the TGF- $\beta$ family of polypeptides. Furthermore, bFGF and PDGF BB, but not IGF-I, opposed the stimulatory effect of BMP-2 on noggin expression. The significance of this effect is not immediately apparent, although bFGF and PDGF BB tend to have opposite actions on osteoblasts as those described for BMPs and decrease the differentiated function of the osteoblast $(17,37,41,42)$. A decrease in noggin could be a compensatory mechanism to maintain the differentiated function of the osteoblast when cells are ex- posed to mitogenic growth factors, such as bFGF and PDGF $\mathrm{BB}$. The effect of BMP-2 on noggin expression was not specific to osteoblastic cells and was also observed in skin fibroblasts.

The induction of noggin by BMPs suggests a potential role for noggin in the regulation of BMP action in the skeletal system. BMPs have important effects on bone remodeling, and recent studies confirmed the expression of BMP receptors in bone cells (45). Some of the actions of BMPs on skeletal cells are probably due to direct regulation of osteoblastic genes. In the present studies, we confirm that BMP-2 has modest mitogenic properties for $\mathrm{Ob}$ cells, stimulates collagen and noncollagen protein synthesis, and increases APA in osteoblasts (9). Noggin decreased the biological effects of BMP-2, -4 , and -6 on osteoblastic function, indicating that it is capable of attenuating the effects of BMPs in osteoblasts. These observations, in conjunction with an induction of noggin following exposure to BMPs, indicate a possible role for noggin in limiting the actions of BMPs in skeletal cells. It is particularly intriguing that noggin is virtually not expressed by unstimulated cells. This would suggest the possibility that noggin does not have other functions in osteoblastic cells and acts as an inducible binding protein for BMPs to prevent overexposure of osteoblasts to the morphogenetic proteins. Furthermore, there have been no reports of direct cellular actions of noggin or of the existence of specific noggin receptors. The slight increase in BMP-4 


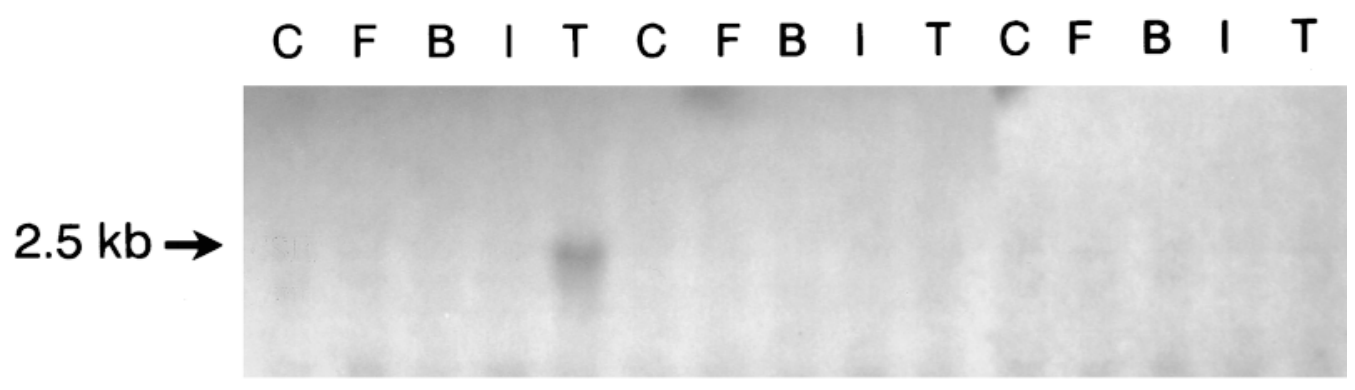

$18 S$
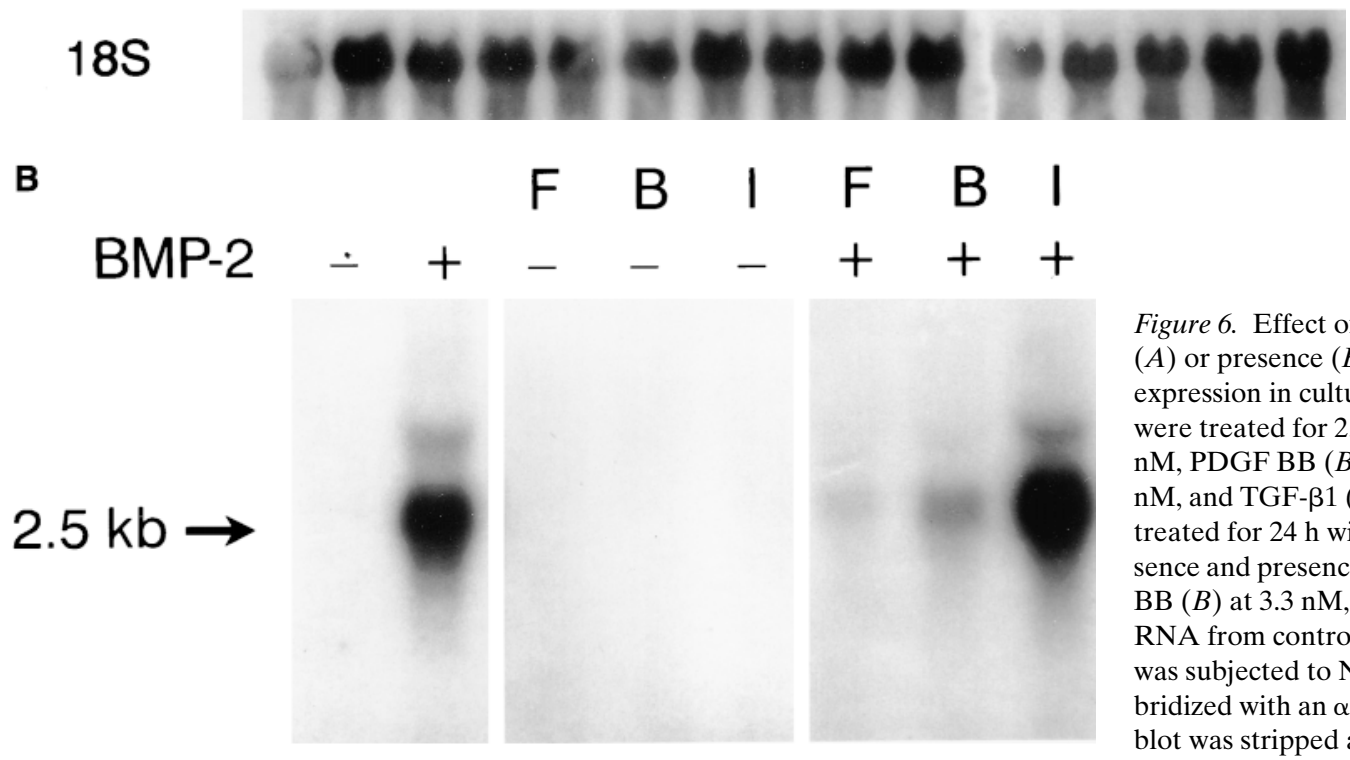

$\begin{array}{llllll}\text { F } & B & \text { I } & \text { F } & \text { B } & \text { I }\end{array}$ $18 \mathrm{~S}$


Figure 6. Effect of growth factors in the absence $(A)$ or presence $(B)$ of BMP-2 on noggin mRNA expression in cultures of $\mathrm{Ob}$ cells. $(A) \mathrm{Ob}$ cells were treated for 2,6 , or $24 \mathrm{~h}$ with bFGF $(F)$ at 1.7 $\mathrm{nM}$, PDGF BB $(B)$ at $3.3 \mathrm{nM}$, IGF-I $(I)$ at 100 $\mathrm{nM}$, and TGF- $\beta 1(T)$ at $1.2 \mathrm{nM}$. $(B)$ Ob cells were treated for $24 \mathrm{~h}$ with BMP-2 at $3.3 \mathrm{nM}$ in the absence and presence of $\operatorname{bFGF}(F)$ at $1.7 \mathrm{nM}$, PDGF $\mathrm{BB}(B)$ at $3.3 \mathrm{nM}$, and IGF-I $(I)$ at $100 \mathrm{nM}$. Total RNA from control $(C$ or -$)$ or treated cultures was subjected to Northern blot analysis and hybridized with an $\alpha{ }^{32} \mathrm{P}$-labeled noggin cDNA. The blot was stripped and rehybridized with labeled $18 \mathrm{~S}$ cDNA. Noggin mRNA was visualized by autoradiography and is shown in the upper panels, while $18 \mathrm{~S}$ ribosomal RNA is shown in the lower panels.

mRNA levels following treatment with noggin suggests local feedback mechanisms controlling BMP-4 expression, since noggin probably acted by binding BMPs secreted by osteoblasts.

\section{TGF $\beta \quad 0 \quad 0.4 \quad 4 \quad 404001200$ pM}

$18 S$

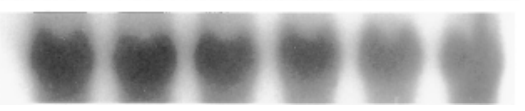

Figure 7. Effect of TGF- $\beta 1$ at $0.4-1,200$ pM on noggin mRNA expression in cultures of $\mathrm{Ob}$ cells treated for $2 \mathrm{~h}$. Total RNA from control (0) or treated cultures was subjected to Northern blot analysis and hybridized with an $\alpha{ }^{-32} \mathrm{P}$-labeled noggin cDNA. The blot was stripped and rehybridized with labeled $18 \mathrm{~S}$ cDNA. Noggin mRNA was visualized by autoradiography and is shown in the upper panel while $18 \mathrm{~S}$ ribosomal RNA is shown below.
The induction of noggin by BMPs should not be surprising and noggin may regulate the amount of effective or biologically available BMPs in a manner analogous to that described for IGFs and IGF binding proteins (IGFBPs) (46). Frequently, agents that induce IGF-I expression also enhance the synthesis of selected IGFBPs by the osteoblast, suggesting a possible role for these proteins in limiting the activity of IGF-I in bone $(47,48)$. IGF-I is known to induce the transcription of IGFBP-5 and to stabilize the protein (49). However, the effects of IGFBP-5 in osteoblasts are complex, and this IGFBP can stimulate or inhibit bone cell growth depending on experimental conditions (50). Therefore, growth factor induction of a binding protein that only blocks the actions of the inducing factor in bone seems to be more selective to BMPs and noggin. Binding proteins for other members of the TGF- $\beta$ family of peptides also have been reported. Follistatin binds and regulates the activity of activin in skeletal and nonskeletal cells, and while there are no reports of follistatin induction by activin or other members of the TGF- $\beta$ family of peptides in skeletal cells, activin A increases follistatin mRNA levels in hepatocytes (51-54). It is possible that a similar effect occurs in osteoblasts and that various members of the TGF- $\beta$ family of peptides use similar mechanisms to control the availability of the growth factor to target cells. The induction of noggin by BMPs may be a necessary protective mechanism to avoid ex- 

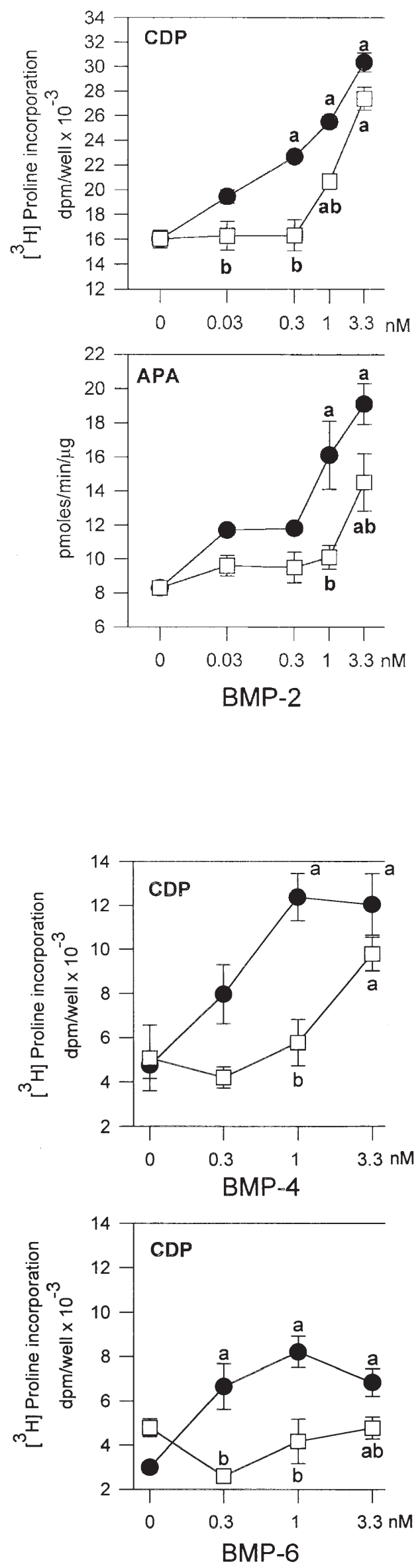


Figure 8. Effect of BMP-2, in the presence and absence of noggin at $1.8 \mathrm{nM}$, on ${ }^{3} \mathrm{H}-$ labeled proline incorporation into CDP and NCP, APA, and $\left[{ }^{3} \mathrm{H}\right]$ thymidine incorporation into DNA in $\mathrm{Ob}$ cells treated for $24 \mathrm{~h}$. Values represent means \pm SEM for five or six cultures. (a) Significantly higher than control DMEM, $P<0.05$, and $(b)$ significantly lower than BMP-2 alone, $P<0.05$.


Figure 9. Effect of BMP-4 and BMP-6 in the presence and absence of noggin at 1.8 $\mathrm{nM}$, on ${ }^{3} \mathrm{H}$-labeled proline incorporation into $\mathrm{CDP}$ and $\left[{ }^{3} \mathrm{H}\right]$ thymidine incorporation into DNA in Ob cells treated for $24 \mathrm{~h}$. Values represent means \pm SEM for five or six cultures. (a) Significantly higher than control DMEM, $P<0.05$, and $(b)$ significantly lower than BMP-4 or BMP-6 alone, $P<0.05$. 
cessive exposure of skeletal cells to BMPs. In fact, clinical observations have demonstrated overexpression of BMP-4 in peripheral lymphocytes of patients with fibrodysplasia ossificans progressiva, suggesting that excessive exposure to BMPs is not beneficial and may lead to serious disease (28).

Recent investigations revealed serious developmental abnormalities in the skeletons of mice with a homozygous noggin mutation (55). The prevailing defect in mice lacking noggin was failure to develop joints. Multiple skeletal defects, including loss of caudal vertebrae and shortened body axis were noted, and the skeletal phenotype was attributed to actions of unopposed BMPs (55). This would indicate that noggin plays an autocrine role, regulating the skeletal function of BMPs. An attempt was made at confirming the autocrine role of noggin in cultured osteoblasts by performing antibody neutralization experiments using noggin-blocking antibodies. In preliminary experiments, these antibodies enhanced the activity of BMP-2 on DNA and collagen synthesis in Ob cells (data not shown). However, control antibodies were not available for testing and nonspecific IgG inhibited control and BMP-2 effects on collagen synthesis and had erratic effects on DNA synthesis, making the blocking antibody data not definitive. Osteoblasts from noggin knockout mice could not be obtained to test the autocrine role of noggin because the phenotype is lethal (55).

In conclusion, the present studies demonstrate that BMPs cause an induction of noggin mRNA and protein levels in skeletal cells by transcriptional mechanisms, and noggin prevents the effects of BMPs in osteoblasts. The induction of noggin by BMPs appears to be a mechanism to limit BMP effects in bone.

\section{Acknowledgments}

The authors thank Regeneron Pharmaceuticals, Inc., for noggin, noggin antibodies, and noggin cDNA, Genetics Institute for BMP-2, -4, and -6 and respective cDNAs, Eddy De Robertis for chordin cDNA, Genentech for TGF- $\beta 1$, Ms. Cathy Boucher, Ms. Deena Durant, Ms. Sheila Rydziel, Ms. Susan O'Lone, and Ms. Kristine Sasala for technical assistance, and Mrs. Margaret Nagle and Ms. Charlene Gobeli for secretarial help.

This work was supported by Grant AR21707 from the National Institute of Arthritis, Musculoskeletal and Skin Diseases.

\section{References}

1. Wozney, J.M., V. Rosen, A.J. Celeste, L.M. Mitsock, M.J. Whitters, R.W. Kriz, R.M. Hewick, and E.A. Wang. 1988. Novel regulators of bone formation: molecular clones and activities. Science. 242:1528-1534.

2. Celeste, A.J., J.A. Iannazzi, R.C. Taylor, R.M. Hewick, V. Rosen, E.A. Wang, and J.M. Wozney. 1990. Identification of transforming growth factor B family members present in bone-inductive protein purified from bovine bone. Proc. Natl. Acad. Sci. USA. 87:9843-9847.

3. Luyten, F.P., N.S. Cunningham, S. Ma, N. Muthukumaran, R.G. Hammonds, W.B. Nevins, W.I. Wood, and A.H. Reddi. 1989. Purification and partial amino acid sequence of osteogenin, a protein initiating bone differentiation. J. Biol. Chem. 264:13377-13380.

4. Luyten, F.P., Y.M. Yu, M. Yanagishita, S. Vukicevic, R.G. Hammonds, and A.H. Reddi. 1992. Natural bovine osteogenin and recombinant human bone morphogenetic protein-2B are equipotent in the maintenance of proteoglycans in bovine articular cartilage explant cultures. J. Biol. Chem. 267: 3691-3695.

5. Ozkaynak, E., D.C. Rueger, E.A. Drier, C. Corbett, R.J. Ridge, T.K. Sampath, and H. Oppermann. 1990. Op-1 cDNA encodes an osteogenic protein in the TGF- $\beta$ family. EMBO J. 9:2085-2093.

6. Ozkaynak, E., P.N.J. Schnegelsberg, D.F. Jin, G.M. Clifford, F.D. Warren, E.A. Drier, and H. Oppermann. 1992. Osteogenic protein-2. A new mem- ber of the transforming growth factor- $\beta$ superfamily expressed early in embryogenesis. J. Biol. Chem. 267:25220-25227.

7. Jones, C.M., D. Simon-Chazottes, J.-L. Guenet, and B.L.M. Hogan. 1992 Isolation of $\mathrm{Vgr}-2$, a novel member of the transforming growth factor- $\beta$-related gene family. Mol. Endocrinol. 6:1961-1968.

8. Wang, E.A., V. Rosen, J.S. D'Alessandro, M. Bauduy, P. Cordes, T. Harada, D.I. Israel, R.M. Hewick, K.M. Kerns, P. LaPan, et al. 1990. Recombinant human bone morphogenetic protein induces bone formation. Proc. Natl. Acad. Sci. USA. 87:2220-2224.

9. Chen, T.L., R.L. Bates, A. Dudley, R.G. Hammonds, Jr., and E.P. Amento. 1991. Bone morphogenetic protein-2b stimulation of growth and osteogenic phenotypes in rat osteoblast-like cells: comparison with TGF 31 . $J$. Bone Miner. Res. 6:1387-1393.

10. Takuwa, Y., C. Ohse, E.A. Wang, J.M. Wozney, and K. Yamashita. 1991. Bone morphogenetic protein-2 stimulates alkaline phosphatase activity and collagen synthesis in cultured osteoblastic cells, MC3T3-E1. Biochem. Biophys. Res. Commun. 174:96-101.

11. Yamaguchi, A., T. Katagiri, T. Ikeda, J.M. Wozney, V. Rosen, E.A Wang, A.J. Kahn, T. Suda, and S. Yoshiki. 1991. Recombinant human bone morphogenetic protein-2 stimulates osteoblastic maturation and inhibits myogenic differentiation in vitro. J. Cell Biol. 113:681-687.

12. Thies, R.S., M. Bauduy, B.A. Ashton, L. Kurtzberg, J.M. Wozney, and V. Rosen. 1992. Recombinant human bone morphogenetic protein-2 induces osteoblastic differentiation in W-20-17 stromal cells. Endocrinology. 130:13181324.

13. Hughes, F.J., J. Collyer, M. Stanfield, and S.A. Goodman. 1995. The effects of bone morphogenetic protein-2, -4 , and -6 on differentiation of rat osteoblast cells in vitro. Endocrinology. 136:2671-2677.

14. Varghese, S., and E. Canalis. 1997. Regulation of collagenase- 3 by bone morphogenetic protein-2 in bone cell cultures. Endocrinology. 138:1035-1040.

15. Ghosh-Choudhury, N., M.A. Harris, J.Q. Feng, G.R. Mundy, and S.E. Harris. 1994. Expression of the BMP 2 gene during bone cell differentiation. Crit. Rev. Eukaryot. Gene Expr. 4:345-355.

16. Boden, S.C., G. Hair, L. Titus, M. Racine, K. McCuaig, J.M. Wozney, and M.S. Nanes. 1997. Glucocorticoid-induced differentiation of fetal rat calvarial osteoblasts is mediated by bone morphogenetic protein-6. Endocrinology. 138:2820-2828.

17. Canalis, E., J. Pash, and S. Varghese. 1993. Skeletal growth factors. Crit. Rev. Eukaryot. Gene Expr. 3:155-166.

18. ten Dijke, P., H. Yamashita, T.K. Sampath, A.H. Reddi, M. Estevez, D.L. Riddle, H. Ichijo, C.-H. Heldin, and K. Miyazono. 1994. Identification of type I receptors for osteogenic protein-1 and bone morphogenetic protein-4. J. Biol. Chem. 269:16985-16988.

19. Penton, A., Y. Chen, K. Staehling-Hampton, J.L. Wrana, L. Attisano, J. Szidonya, J.A. Cassill, J. Massague, and F.M. Hoffmann. 1994. Identification of two bone morphogenetic protein type I receptors in drosophila and evidence that Brk25D is a decapentaplegic receptor. Cell. 78:239-250.

20. Rosenzweig, B.L., T. Imamura, T. Okadome, G.N. Cox, H. Yamashita, P. ten Dijke, C.-H. Heldin, and K. Miyazono. 1995. Cloning and characterization of a human type II receptor for bone morphogenetic proteins. Proc. Natl. Acad. Sci. USA. 92:7632-7636.

21. Letsou, A., K. Arora, J.L. Wrana, K. Simin, V. Twombly, J. Jamal, K. Staehling-Hampton, F.M. Hoffmann, W.M. Gelbart, J. Massague, et al. 1995. Drosophila dpp signaling is mediated by the punt gene product: a dual ligandbinding type II receptor of the TGF $\beta$ receptor family. Cell. 80:899-908.

22. Smith, W.C., and R.M. Harland. 1992. Expression cloning of noggin, a new dorsalizing factor localized to the Spemann organizer in xenopus embryos. Cell. 70:829-840.

23. Sasai, Y., B. Lu, H. Steinbeisser, D. Geissert, L.K. Gont, and E.M. De Robertis. 1994. Xenopus chordin: A novel dorsalizing factor activated by organizer-specific homeobox genes. Cell. 79:779-790.

24. Zimmerman, L.B., J.M. DeJesus-Escobar, and R.M. Harland. 1996. The Spemann organizer signal noggin binds and inactivates bone morphogenetic protein-4. Cell. 86:599-606.

25. Holley, S.A., J.L. Neul, L. Attisano, J.L. Wrana, Y. Sasai, M.B. O'Connor, E.M. De Robertis, and E.L. Ferguson. 1996. The Xenopus dorsalizing factor noggin ventralizes drosophila embryos by preventing dpp from activating its receptor. Cell. 86:607-617.

26. Piccolo, S., Y. Sasai, B. Lu, and E.M. De Robertis. 1996. Dorsoventral patterning in xenopus: inhibition of ventral signals by direct binding of chordin to BMP-4. Cell. 86:589-598.

27. Valenzuela, D.M., A.N. Economides, E. Rojas, T.M. Lamb, L. Nunez, P. Jones, N.Y. Ip, R. Espinosa III, C.I. Brannan, D.J. Gilbert, et al. 1995. Identification of mammalian noggin and its expression in the adult nervous system. $J$. Neurosci. 15:6077-6084.

28. Shafrtiz, A.B., E.M. Shore, F.H. Gannon, M.A. Zasloff, R. Taub, M Muenke, and F.S. Kaplan. 1996. Overexpression of an osteogenic morphogen in fibrodysplasia ossificans progressiva. N. Engl. J. Med. 335:555-561.

29. McCarthy, T.L., M. Centrella, and E. Canalis. 1988. Further biochemical and molecular characterization of primary rat parietal bone cell cultures. $J$ Bone Miner. Res. 3:401-408.

30. Delany, A.M., J.J. Jeffrey, S. Rydziel, and E. Canalis. 1995. Cortisol in- 
creases interstitial collagenase expression in osteoblasts by post-transcriptional mechanisms. J. Biol. Chem. 270:26607-26612.

31. Sudo, H., H.-A. Kodama, Y. Amagai, S. Yamamoto, and S. Kasai. 1983. In vitro differentiation and calcification in a new clonal osteogenic cell line derived from newborn mouse calvaria. J. Cell Biol. 96:191-198.

32. Feinberg, A.P., and B. Vogelstein. 1984. A technique for radiolabeling DNA restriction endonuclease fragments to high specific activity. Anal. Biochem. 137:266-267.

33. Ausubel, F.M., R. Brent, R.E. Kingston, D.D. Moore, J.G. Siedman, J.A. Smith, and K. Struhl. 1995. Identification of newly transcribed RNA. In Current Protocols in Molecular Biology. John Wiley \& Sons Inc., New York. 4.10.1-4.10.10.

34. Knudsen, B.S., P.C. Harpel, and R.L. Nachman. 1987. Plasminogen activator inhibitor is associated with the extracellular matrix of cultured bovine smooth muscle cells. J. Clin. Invest. 80:1082-1089.

35. Jones, J.I., A. Gockerman, W.H. Busby, Jr., C. Camacho-Hubner, and D.R. Clemmons. 1993. Extracellular matrix contains insulin-like growth factor binding protein-5: potentiation of the effects of IGF-I. J. Cell Biol. 121:679-687.

36. Laemmli, U.K. 1970. Cleavage of structural protein during the assembly of the head bacteriophage T4. Nature. 277:680-685.

37. Hock, J.M., M. Centrella, and E. Canalis. 1988. Insulin-like growth factor I (IGF-I) has independent effects on bone matrix formation and cell replication. Endocrinology. 122:254-260.

38. Peterkofsky, B., and R. Diegelmann. 1971. Use of a mixture of proteinase-free collagenases for the specific assay of radioactive collagen in the presence of other proteins. Biochemistry. 10:988-994 York.

39. Wall, F.J. 1986. Statistical Data Analysis Handbook. McGraw-Hill, New

40. Centrella, M., T.L. McCarthy, and E. Canalis. 1991. Glucocorticoid regulation of transforming growth factor $\beta$ (TGF $\beta$ ) activity and binding in osteoblast-enriched cultures from fetal rat bone. Mol. Cell. Biol. 11:4490-4496.

41. Centrella, M., T.L. McCarthy, W.F. Kusmik, and E. Canalis. 1991. Relative binding and biochemical effects of heterodimeric and homodimeric isoforms of platelet-derived growth factor in osteoblast-enriched cultures from fetal rat bone. J. Cell. Physiol. 147:420-426.

42. McCarthy, T.L., M. Centrella, and E. Canalis. 1989. Effects of fibroblast growth factors on deoxyribonucleic acid and collagen synthesis in rat parietal bone cells. Endocrinology. 125:2118-2126.

43. Canalis, E., M. Centrella, and M.R. Urist. 1985. Effect of partially puri- fied bone morphogenetic protein on DNA synthesis and cell replication in calvarial and fibroblast cultures. Clin. Orthop. 198:289-296.

44. Centrella, M., T. McCarthy, and E. Canalis. 1987. Transforming growth factor Beta is a bifunctional regulator of replication and collagen synthesis in osteoblast-enriched cell cultures from fetal rat bone. J. Biol. Chem. 262:28692874 .

45. Iwasaki, S., N. Tsuruoka, A. Hattori, M. Sato, M. Tsujimoto, and M Kohno. 1995. Distribution and characterization of specific cellular binding proteins for bone morphogenetic protein-2. J. Biol. Chem. 270:5476-5482.

46. Rechler, M.M. 1993. Insulin-like growth factor binding proteins. Vitam. Horm. 47:1-114.

47. McCarthy, T.L., M. Centrella, and E. Canalis. 1990. Cyclic AMP induces insulin-like growth factor I synthesis in osteoblast-enriched cultures. J. Biol. Chem. 265:15353-15356.

48. McCarthy, T., S. Casinghino, M. Centrella, and E. Canalis. 1994. Complex pattern of insulin-like growth factor binding protein expression in primary rat osteoblast enriched cultures: regulation by prostaglandin $\mathrm{E}_{2}$, growth hormone, and the insulin-like growth factors. J. Cell. Physiol. 160:163-175.

49. Dong, Y., and E. Canalis. 1995. Insulin-like growth factor I and retinoic acid induce the synthesis of insulin-like growth factor binding protein-5 in rat osteoblastic cells. Endocrinology. 136:2000-2006.

50. Andress, D.L., and R.S. Birnbaum. 1992. Human osteoblast-derived insulin-like growth factor (IGF) binding protein-5 stimulates osteoblast mitogenesis and potentiates IGF action. J. Biol. Chem. 267:22467-22472.

51. Nakamura, T., K. Takio, Y. Eto, H. Shibai, K. Titani, and H. Sugino. 1990. Activin-binding protein from rat ovary is follistatin. Science. 247:836-838.

52. Hashimoto, M., A. Shoda, S. Inoue, R. Yamada, T. Kondo, T. Sakurai, N. Ueno, and M. Muramatsu. 1992. Functional regulation of osteoblastic cells by the interaction of activin-A with follistatin. J. Biol. Chem. 267:4999-5004.

53. Funaba, M., K. Ogawa, T. Murata, H. Fujimura, E. Murata, M. Abe, M. Takahashi, and K. Torii. 1996. Follistatin and activin in bone: expression and localization during endochondral bone development. Endocrinology. 137:42504259 .

54. Zhang, Y.-Q., M. Kanzaki, H. Shibata, and I. Kojima. 1997. Regulation of the expression of follistatin in rat hepatocytes. Biochem. Biophys. Acta. 1354: 204-210.

55. Brunet, L.J., J.A. McMahon, A.P. McMahon, and R.M. Harland. 1998 Noggin, cartilage morphogenesis, and joint formation in the mammalian skeleton. Science. 280:1455-1457. 